\title{
ZOOPLANKTON ASSEMBLAGES FROM A TIDAL CHANNEL IN THE BAHÍA BLANCA ESTUARY, ARGENTINA*
}

\author{
Mónica Susana Hoffmeyer ${ }^{1,3}$ \& María Sonia Barría de Cao ${ }^{1,2}$ \\ ${ }^{1}$ Instituto Argentino de Oceanografía -IADO- (CONICET-UNS) \\ (Camino La Carrindanga km 7, (B 8000 FWB), Bahía Blanca, Argentina) \\ e-mail: bmhoffme@criba.edu.ar \\ ${ }^{2}$ Universidad Nacional del Sur, Departamento de Biología, Bioquímica y Farmacia \\ (San Juan 670, 8000 Bahía Blanca, Argentina) \\ ${ }^{3}$ Universidad Tecnológica Nacional. Facultad Regional Bahía Blanca \\ (11 de Abril 461, 8000 Bahía Blanca, Argentina)
}

\begin{abstract}
A B S T R A C T
In this study we investigate for the first time the zooplankton assemblages in a relatively small tidal channel called Bahía del Medio, situated in the middle-outer area of the Bahía Blanca Estuary, South of the Main channel. We focused the study on micro- and mesozooplankton assemblages with emphasis on tintinnids, copepods and meroplankton along the annual cycle 1997-1998. Fifteen species of tintinnids belonging to 6 genera were observed in the study area, the mean total tintinnid abundance fluctuating between $3.4 \times 10^{6}$ ind. $\mathrm{m}^{-3}$ and $5.1 \times 10^{6}$ ind $\mathrm{m}^{-3}$. The mesozooplankton comprised 11 taxa, total abundance fluctuating between 449 ind $\mathrm{m}^{-3}$ in March 1997 and only 1 ind $\mathrm{m}^{-3}$ in October 1997. The channel proved to be spatially homogeneous in its physical and biochemical features. Micro- and mesozooplankton abundance displayed a high degree of spatial homogeneity, though the seasonal variation in both environment and zooplankton was significant. Comparison with the zooplankton observed at a station in the Main channel of the estuary showed differences in number of taxa represented, a general lower abundance of both assemblages and the presence of some rare species, a fact which is discussed.
\end{abstract}

\section{RESUMO}

Neste estudo pesquisamos pela primeira vez as associações do zooplâncton num pequeno canal de maré, relativamente novo e chamado Bahía del Medio, localizado na região média-exterior do estuário da Bahía Blanca e ao sul do canal principal. Focalizamos o estudo no micro- e mesozooplâncton com ênfase nos grupos Tintinnida, Copepoda e meroplâncton, ao longo do ciclo anual 1997-1998. Foram observadas 15 espécies de Tintinnida pertencentes a 6 gêneros; a abundância média total de Tintinnida variou entre $3,4 \times 10^{6}$ ind. $\mathrm{m}^{-3}$ e $5,1 \times 10^{6}$ ind. $\mathrm{m}^{-3}$. $\mathrm{O}$ mesozooplâncton apresentou 11 taxa e uma abundância total entre 449 ind. $\mathrm{m}^{-3} \mathrm{em}$ março de1997 e 1 ind. $\mathrm{m}^{-3} \mathrm{em}$ outubro de 1997. O canal provou ser espacialmente homogêneo em suas características biológicas, químicas e físicas. A abundância do micro- e mesozooplâncton mostrou um alto grau de homogeneidade espacial, embora a variaçao estacional fosse significativa nas características do meio ambiente e do zooplâncton. A comparação com o zooplâncton observado em uma estação de amostragem no canal principal do estuário mostrou diferenças no número de taxa, na abundância, em geral mais baixa, e na presença de algumas espécies raras, fato esse comentado.

Descriptors: Tidal channel, MICROZOOPLANKTON, Tintinnids, MESOZOOPLANKTON, Copepods, Meroplankton, Estuary, Seasonal variation

Descritores: Canal de maré, Microzooplâncton, Tintinnida, Mesozooplâncton, Copepoda, Meroplâncton, Estuário, Variaçao estacional.

\section{INTRODUCTION}

In estuaries, zooplankton assemblage characteristics and its spatial distribution are mainly influenced by the circulation pattern and tides (Valiela, 1995). These factors produce strong effects on the

(*) Paper presented at the $2^{\text {nd }}$ Brazilian Congress of Oceanography, on 09-12 October 2005. Vitória, Brazil. horizontal distribution of meroplankton forms (Seliger et al., 1982). The complex hydrodynamics of the Bahía Blanca estuary combined with other factors influence both biodiversity of microzooplankton (Barría de Cao et al., 2006) and horizontal distribution by means of the passive transport of planktonic larvae (Cervellini, 2001).

The study environment is a turbid and temperate estuary classified as mesotidal, located on the Atlantic coast of Argentina at $38^{\circ} 42^{\prime}-39^{\circ} 25^{\prime} \mathrm{S}$; 
$61^{\circ} 50^{\prime}-62^{\circ} 22^{\prime} \mathrm{W}$ (Fig. 1) and comprising an area of $2,300 \mathrm{~km}^{2}$ at low tide (Angeles, 2002). It is made up of a complex network of tidal channels, extensive tidal flats, low marshes and islands (Ginsberg \& Perillo, 2004). The general circulation is dominated by a stationary and semidiurnal tidal wave (Serman, 1985). The Sauce Chico River (basin of $1,600 \mathrm{~km}^{2}$ ), the Napostá Grande Stream $\left(920 \mathrm{~km}^{2}\right)$ and other minor creeks provide a less freshwater flow increasing along the year only during rainfall periods. (Pettigrosso et al., 1997). The Main channel of the estuary constitutes the access to an important harbour complex (Galvan, White \& Rosales Ports) on the Argentine coast; its mean depth is $10 \mathrm{~m}$, maintained by means of dredging, with depths up to about $22 \mathrm{~m}$ at the mouth (Aliotta \& Perillo, 1987).

Piccolo \& Perillo (1990) distinguished two sectors in the Main channel of the estuary based on the distribution of temperature and salinity values. The inner area extends from Ing. White Port up to the estuarine head and is partially mixed during normalhigh runoff conditions, with a strong tendency to become transversely homogeneous during low runoff.

Though abundant data on the plankton from the Main channel are available, there is a comparative lack of knowledge on plankton from the channel systems located at the southernmost part of the Bahía
Blanca Estuary (Falsa Bay, Verde Bay, Brightman Cove and secondary small channels towards the south from the Main channel which is an almost unexplored region (Piccolo \& Hoffmeyer, 2004).

The different types of channels occurring within the Bahía Blanca estuary are large tidal channels, creeks and gullies and smaller channels in general, presenting a reversible circulation (Ginsberg $\&$ Perillo, 2004). Different plankton associations can inhabit these channels, depending on the geomorphologic and hydrodynamic characteristics, with some differences in composition from those known to occur along the Main channel of the estuary, and perhaps giving rise to some differences in the particular spatial and seasonal pattern.

In this study we investigate, for the first time, the zooplankton assemblages at a relatively small tidal channel named Bahía del Medio, situated in the middle-outer area of the Bahía Blanca estuary. This channel forms part of a particular looping channel system in the southern area of the Main channel (La Lista - Cabeza de Buey channels), with interconnected islands, channels of different sizes and tidal flats (Fig. 1). Its course is sinuous and meandering, and its depth varies between 1 and $8 \mathrm{~m}$; during spring tides the tidal amplitude reaches up to $4 \mathrm{~m}$ (Cuadrado et al., 2000).

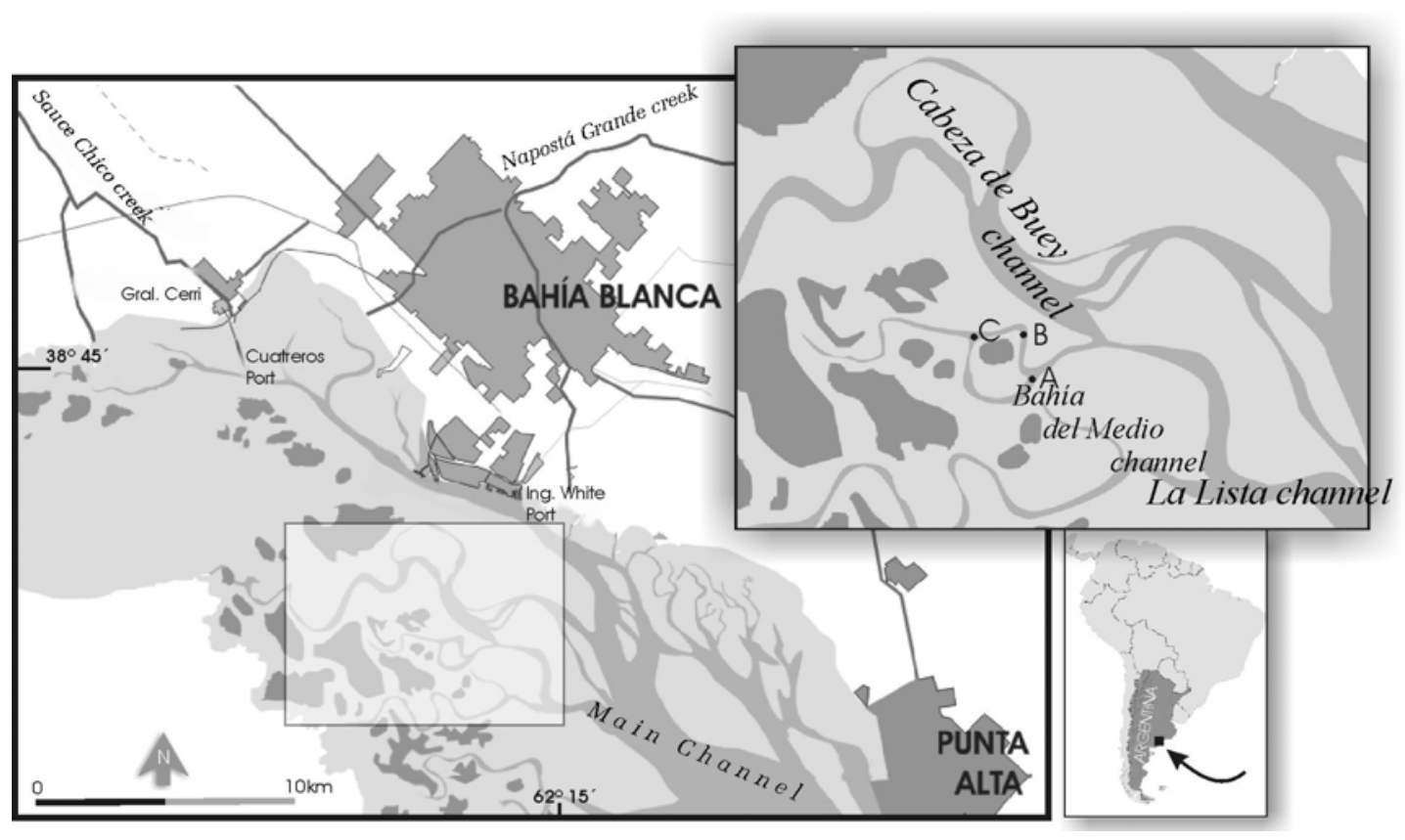

Fig. 1. Map of the study area. Bahía del Medio tidal channel and its location within the Bahía Blanca Estuary. 
The bottom of the channel is formed mainly by fine sediments, slime and sand (Aliotta et al., 1998). A high content of suspended sediments is also a common feature of the water column. Based on the estimating bedload net sediment transport, a circulation model was inferred for the La Lista Cabeza de Buey channels system with a net dominance of ebb tide effects on its hydrodynamics (Ginsberg, pers. comm.). Despite its location close to the most polluted zone in the estuary (innermost zone towards the NW), the channel's features make it favourable for aquaculture development (low concentration of heavy metals and hydrocarbons, geomorphologic conditions providing protection against storms, strong winds and large waves). From the microbiological point of view it has also been demonstrated to be suitable for aquaculture (Baldini et al., 1999).

The work focuses particularly on the zooplankton composition, number of taxa, their abundance and seasonal variation in relation to physical, chemical and biochemical variables all along the annual cycle 1997-1998. Particular emphasis is placed on tintinnids, the main group within the microzooplankton, and on copepods and meroplankton, the two major groups among the mesozooplankton in the Bahía Blanca estuary (Barría de Cao, 1992; Hoffmeyer, 1983; 1994; 2004 a, b). The zooplankton characteristics found at this tidal channel are compared with those observed in previous years at Ing. White Port station (Fig. 1) which is located in the innermost zone of Main channel estuary. The working hypothesis is that the differences found in the zooplankton assemblages of the tidal channel with respect to those of the Main channel are due to the particular hydrodynamics of that channel.

\section{Materials And Methods}

Monthly sampling was carried out during daylight and ebb tide from $03 / 18 / 97$ to $05 / 20 / 98$ at three fixed stations $\mathrm{A}, \mathrm{B}$ and $\mathrm{C}$ located at Bahía del Medio tidal channel (Fig. 1).

Microzooplankton samples were collected at subsurface level with a Van-Dorn bottle and fixed with Lugol's solution. Further samples were collected with a small $30 \mu \mathrm{m}$ mesh plankton net. Mesozooplankton samples were collected with a $200 \mu \mathrm{m}$ mesh- $0.30 \mathrm{~m}$ open-mouth net, through horizontal tows in the $5 \mathrm{~m}$ surface layer during $5 \mathrm{~min}$ at two knots velocity. Surface temperature values were measured in situ and salinity, particulate organic carbon (POM), dissolved oxygen, inorganic nutrients (nitrites, nitrates, phosphates and silicates), chlorophyll $a$ and phaeopigments of surface samples were determined in the laboratory following the techniques of Strickland \& Parsons (1968) and Lorenzen (1967).
For tintinnid counting, $50 \mathrm{ml}$ subsamples representing material from $250 \mathrm{ml}$ were concentrated after settling in a combined plate chamber. The entire bottom chamber was scanned for each subsample using an inverted microscope following the Utermöhl method after Hasle (1978). Mesozooplankton samples were qualitatively and quantitatively analysed under stereomicroscope. Identification was done up to the lowest taxonomic level.

Basic descriptive parametric statistics was applied to physico-chemical and biochemical variables and zooplankton abundance data. The "t" test was used on environmental variable data to analyse differences among stations. Pearson linear correlation coefficient (Sokal \& Rohlf, 1981) was calculated to analyse the relationships among all the variables for each station and micro- and mesozooplankton. The correlation between total tintinnid abundance and the abundance of the omnivorous copepod Acartia tonsa was also calculated. Two-way analysis of variance (ANOVA) was applied to micro- and mesozooplankton abundance data as well as to variable data to test for significant differences between dates and sites in both the zooplankton seasonal and spatial distribution pattern and the environmental pattern. Correlations and ANOVA were calculated using $\log$ transformed data $\left(\mathrm{N}^{\mathrm{o}}\right.$ ind $\left.\mathrm{m}^{-3}+1\right)$.

The results obtained on mean abundance and seasonality of micro and mesozooplantkon for this tidal channel were compared with those reported by Barría de Cao (1992) and Hoffmeyer (2004) for the Main channel.

\section{RESULTS}

Maximum temperature was registered at $\mathrm{A}$ (Table 1) and maximum values of nitrites and phosphates, and the minimum of POM, dissolved oxygen and silicates also occurred at this station. Maximum values of salinity, POM, nitrate and chlorophyll $a$ as well as the minimum values of temperature, salinity, nitrites, nitrates, phosphates and chlorophyll $a$ were registered at $\mathrm{B}$. At $\mathrm{C}$ maximum values of silicates and phaeopigments were registered.

Maximum values of nutrients were registered during the autumn, excepting those of silicates obtained during the summer. The maximum value of POM was also obtained during the autumn whereas the maximum value of chlorophyll $a$ was registered during the winter. According to the " $\mathrm{t}$ " test results, no significant differences exist among stations for most of the variables. However, significant differences were found in the concentration of phosphates and silicates between stations $\mathrm{A}$ and $\mathrm{B}$; of nitrates and silicates between $\mathrm{B}$ and $\mathrm{C}$; and of phaeopigments, phosphates and silicates between $\mathrm{C}$ and $\mathrm{A}$. 
Table 1. Annual mean and range values of surface physico chemical and biochemical variables determined at the three stations.

\begin{tabular}{|c|c|c|c|c|c|c|}
\hline \multirow{2}{*}{ Variable } & \multicolumn{2}{|c|}{ St. A } & \multicolumn{2}{|c|}{ St. B } & \multicolumn{2}{|c|}{ St. C } \\
\hline & Mean & Range & Mean & Range & Mean & Range \\
\hline Temperature $\left({ }^{\circ} \mathrm{C}\right)$ & 15.30 & $7.9-19.5$ & 15.51 & $7.19-19.3$ & 15.51 & $8-19.4$ \\
\hline Salinity (psu) & 32.06 & $28.67-36.98$ & 31.99 & $27.78-37.02$ & 32.29 & $28.38-36.98$ \\
\hline Dissolved Oxigen $\left(\mathrm{mg} \mathrm{l}^{-1}\right)$ & 6.05 & 4.84-8.39 & 6.33 & $5.04-7.79$ & 6.40 & $5.46-8.1$ \\
\hline Chlorophyll "a" ( $\left.\mu \mathrm{g} \mathrm{l}^{-1}\right)$ & 8.40 & $1.38-13.45$ & 9.06 & $1.1-24.98$ & 9.29 & $1.56-22.79$ \\
\hline Phaeopigments $\left(\mu \mathrm{g} \mathrm{l}^{-1}\right)$ & 2.86 & $0-9.12$ & 3.05 & $0-6.09$ & 4.25 & $0-9.66$ \\
\hline Particulate organic matter $\left(\mu \mathrm{g} \mathrm{l}^{-1}\right)$ & $1,643.25$ & $522-2,386$ & $1,771.17$ & $810-3,839$ & $1,701.17$ & $1,089-2,371$ \\
\hline Nitrites $(\mathbf{N}-\mu \mathbf{M})$ & 1.95 & $0.1-7.3$ & 1.78 & $0.06-3.91$ & 1.51 & $0.12-6.25$ \\
\hline Nitrates $(\mathbf{N}-\mu M)$ & 7.45 & $0.75-14.16$ & 9.62 & $0.2-33.15$ & 6.52 & $0.39-21.11$ \\
\hline Phosphates (P- $\mu \mathrm{M})$ & 1.74 & $0.63-3.15$ & 1.63 & $0.56-2.54$ & 1.59 & $0.57-2.35$ \\
\hline Silicates (Si- $\mu \mathrm{M})$ & 81.80 & $52.88-99.52$ & 83.24 & $57.5-99.16$ & 90.40 & $60.71-107.17$ \\
\hline
\end{tabular}

Values obtained for all the physical and chemical variables measured at the three stations show them had very similar characteristics (Table 1) during the analysed annual cycle (1997-1998). Maximum salinity values were relatively high at the three stations of this channel and the range wider than that of the Main channel.

Fifteen species of tintinnids belonging to 6 microzooplankton genera were observed in the study area (Table 2). The maximum number of species (9) was registered at station $C$. The mean total tintinnid abundance during the period analysed fluctuated between $3.4 \times 10^{6}$ and $5.1 \times 10^{6}$ ind $\mathrm{m}^{-3}$ at $\mathrm{A}$ and at $\mathrm{C}$, respectively. The maximum abundance value in the tidal channel in 1997 was 33.6 ind $\mathrm{m}^{-3}$ registered at C during the autumn with $19.4^{\circ} \mathrm{C}$. The abundance peaks observed in 1998 reached up to $16.4 \times 10^{6}$ ind at B and $15.8 \times 10^{6}$ ind $\mathrm{m}^{-3}$ at $\mathrm{A}$. They occurred at the beginning of autumn coinciding with temperature values of $19.5^{\circ} \mathrm{C}$ and $19.3^{\circ} \mathrm{C}$ (Fig. 2). Minimum abundance values, such as $0.9 \times 10^{6}$ ind $\mathrm{m}^{-3}$, were registered at $\mathrm{A}$ during winter with a temperature of $10.5^{\circ} \mathrm{C}$ and at $\mathrm{A}$ and $\mathrm{B}$ during spring with temperatures of $13.7^{\circ} \mathrm{C}$ and $21.6^{\circ} \mathrm{C}$, respectively. The first peak, in 1997, was dominated by Metacylis sp. aff. mereschkovskyi (96.1\%). The abundance peaks in 1998 were dominated by Tintinnidium balechi $(93 \%$ and $92 \%$ ) at $\mathrm{A}$ and $\mathrm{B}$.

Total abundance of tintinnids did not correlate with any of the variables measured at station A; the correlations between abundance and dissolved oxygen as well as between abundance and nutrients (nitrites, nitrates and phosphates) were significant ( $\mathrm{p}<$ 0.05 ) at station $\mathrm{B}$. At $\mathrm{C}$ the correlation between abundance and salinity was significant whereas that between abundance and nitrites and abundance and nitrates was highly significant $(\mathrm{p}<0.01)$. The correlation between the abundances of tintinnids and A. tonsa was highly significant $(\mathrm{p}<0.01)$ at stations A and $B$, but was not significant ( $>0.05)$ at St. C.

Table 2. Presence of microzooplankton taxa at the three stations of Bahía del Medio channel, Bahía Blanca Estuary, in 1997-1998 annual cycle.

\begin{tabular}{|c|c|c|c|}
\hline \multirow{2}{*}{ Microzooplankton } & \multicolumn{3}{|c|}{ Station } \\
\hline & $\mathbf{A}$ & $\bar{B}$ & $\mathbf{C}$ \\
\hline \multicolumn{4}{|l|}{ Tintinnida } \\
\hline Tintinnidium balechi & $\mathrm{x}$ & $\mathrm{x}$ & $\mathrm{x}$ \\
\hline T. sp. aff. semiciliatum & $\mathrm{x}$ & $\mathrm{x}$ & $\mathrm{x}$ \\
\hline \multicolumn{4}{|l|}{ Tintinnopsis amphora } \\
\hline T. baltica & $\mathrm{x}$ & $\mathrm{x}$ & $\mathrm{x}$ \\
\hline T. brasiliensis & $\mathrm{x}$ & $\mathrm{x}$ & $\mathrm{x}$ \\
\hline T. beroidea & $\mathrm{x}$ & $\mathrm{x}$ & $\mathrm{x}$ \\
\hline T. glans & $\mathrm{x}$ & $\mathrm{x}$ & $\mathrm{x}$ \\
\hline T. gracilis & & $\mathrm{x}$ & $\mathrm{x}$ \\
\hline T. levigata & & $\mathrm{x}$ & $\mathrm{x}$ \\
\hline T. parva & $\mathrm{x}$ & $\mathrm{x}$ & $\mathrm{x}$ \\
\hline T. parvula & $\mathrm{x}$ & $\mathrm{x}$ & $\mathrm{x}$ \\
\hline Codonellopsis lusitanica & $\mathrm{x}$ & $\mathrm{x}$ & $\mathrm{x}$ \\
\hline Eutintinnus lususundae & & & $\mathrm{x}$ \\
\hline Favella taraikaensis & $\mathrm{x}$ & $\mathrm{x}$ & $\mathrm{x}$ \\
\hline Metacylis sp. aff. mereschkovsky & & $\mathrm{x}$ & $\mathrm{x}$ \\
\hline
\end{tabular}

ANOVA results of total tintinnid abundance did not show significant differences among stations but showed highly significant differences among sampling dates ( $\mathrm{F} 3.7056, \mathrm{p}<0.01)$. ANOVA results of the number of tintinnid species revealed the same trend with non-significant differences among stations but with significant differences among sampling dates (F 2.9622, p <0.05). 


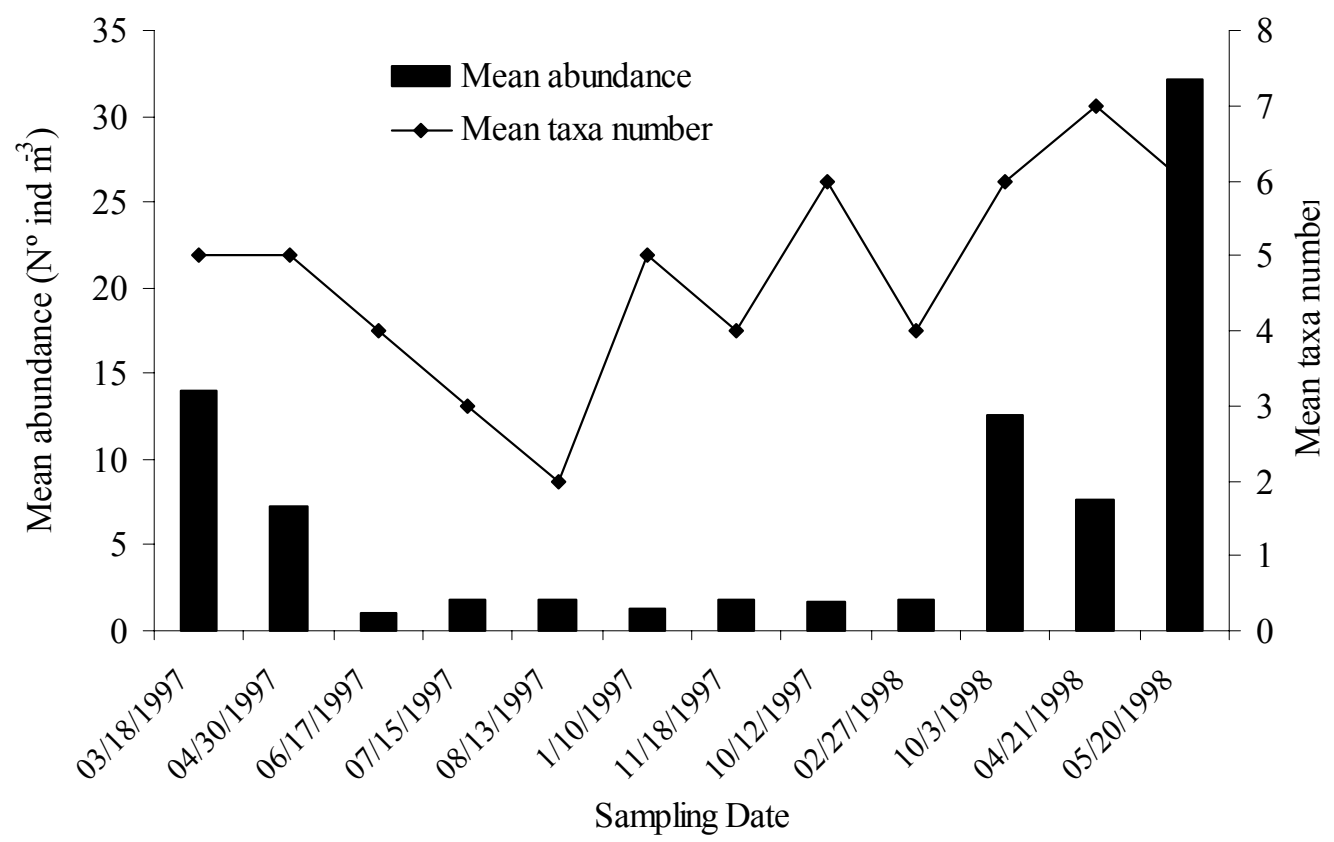

Fig. 2. Seasonal variation of mean taxa number and mean abundance of microzooplankton at Bahía del Medio channel.

The mesozooplankton observed in this study area comprised 11 taxa (Table 3). The maximal numbers (9-11) were registered at all stations in August and November 1997 and the minimal during February- March and May-June 1998. The abundance of total mesozooplankton fluctuated between 449 at station. B in March 1997 and only 1 ind $\mathrm{m}^{-3}$ in October 1997 (Fig. 3). Minimal abundances were found during May-June 1997 and maximal at the end of spring 1997 and the end of summer-autumn of 1998.

Abundance of the total mesozooplankton did not correlate with any of the variables measured at stations $\mathrm{A}$ and $\mathrm{C}$. The relationship with surface temperature was in general important for the three stations data, though a significant correlation $(\mathrm{p}<$ 0.05 ) was only observed at St. B. Two-way ANOVA of total abundance did not show significant differences among stations but highly significant differences were found among dates (F 3.5677, $\mathrm{p}<0.01$ ). ANOVA results of the number of mesozooplanktonic taxa showed the same behaviour (F 10.3246, $\mathrm{p}<0.01)$.

\section{Discussion}

Maximum concentrations of chlorophyll $a$ were obtained during the winter. Gayoso (1999) also reports maximum concentrations of chlorophyll during the winter and early spring in other parts of the estuary's Main channel owing to a phytoplankton bloom occurring yearly which is the most important event in the planktonic seasonal succession in the estuary.

This channel is highly turbid partially due to the large amount of fine sediments in suspension probably coming from the flooding of the tidal flats during high tide. The maximum concentration of total suspended materials can reach $175 \mathrm{mg} \mathrm{l}^{-1}$ in conditions of ebb tide (Cuadrado et al., 2000). The high concentration of particulate organic matter observed in this study is related to the large volume of organic detritus generated in this estuary.

The species richness of tintinnids found in the area was slightly lower than that registered in the Main channel (19) (Barría de Cao, 1992). The maximum was recorded at $\mathrm{C}$. Most of the tintinnid species observed in this study have been reported before for the inner part of the estuary (Barría de Cao, 1992), though some of them, such as Favella taraikaensis, Eutintinnus lususundae and $M$. mereschkovskyi, are typical of the outer zone of the estuary which has more marine influence than the inner shelf (Barría de Cao, 1986).

The mesozooplankton richness at this tidal channel was higher than that reported for the Main channel (Hoffmeyer, 1994; $2004 \mathrm{a}, \mathrm{b}$ ), the maximum being registered at stations $\mathrm{A}$ and $\mathrm{B}$. This fact could be related to new taxa linked to water from the outer 
Table 3. Presence of mesozooplankton taxa at the three stations of Bahía del Medio channel, Bahía Blanca estuary in 1997-1998 annual cycle. Copepods and other groups without indication: adults. Copep: copepodids, $\mathrm{N}-\mathrm{C}$ : nauplius and cypris larva, V: veliger, N1 and N2: nectochaet larva, M: mysis, E: ephira, Z: zoea and megalopa larvae, $\mathrm{C}$ : cerinula larva, $\mathrm{A}$ : actinula larva and $\mathrm{Ci}$ : ciphonautes larva.

\begin{tabular}{|c|c|c|c|}
\hline \multirow{2}{*}{ Mesozooplankton } & \multicolumn{3}{|c|}{ Station } \\
\hline & $\mathbf{A}$ & B & C \\
\hline \multicolumn{4}{|l|}{ Copepoda Calanoida } \\
\hline Acartia tonsa & $\mathrm{x}$ & $\mathrm{x}$ & $\mathrm{x}$ \\
\hline Eurytemora americana & $\mathrm{x}$ & $\mathrm{x}$ & $\mathrm{x}$ \\
\hline Paracalanus parvus & $\mathrm{x}$ & $\mathrm{x}$ & $\mathrm{x}$ \\
\hline Labidocera fluviatilis & $\mathrm{x}$ & & \\
\hline Calanoides carinatus (Copep) & & $\mathrm{x}$ & $\mathrm{x}$ \\
\hline Diaptomidae & $\mathrm{x}$ & & $\mathrm{x}$ \\
\hline \multicolumn{4}{|l|}{ Copepoda Cyclopoida } \\
\hline Oithona nana & & & $\mathrm{x}$ \\
\hline Cyclopina sp. & & $\mathrm{x}$ & \\
\hline Halicyclops crassicornis & $\mathrm{x}$ & $\mathrm{x}$ & \\
\hline \multicolumn{4}{|l|}{ Copepoda Harpacticoida } \\
\hline Euterpina acutifrons & $\mathrm{x}$ & $\mathrm{x}$ & $\mathrm{x}$ \\
\hline Amonardia nordmani & $\mathrm{x}$ & & \\
\hline Tisbe varians & $\mathrm{x}$ & $\mathrm{x}$ & $\mathrm{x}$ \\
\hline Harpacticus chelifer & & $\mathrm{x}$ & \\
\hline Canthocamptidae sp. & & & $\mathrm{x}$ \\
\hline Harpacticoida $1 \mathrm{sp.}$ & $\mathrm{x}$ & $\mathrm{x}$ & $\mathrm{x}$ \\
\hline Harpacticoida $2 \mathrm{sp}$ & $\mathrm{x}$ & $\mathrm{x}$ & $\mathrm{x}$ \\
\hline \multicolumn{4}{|l|}{ Copepoda Monstrilloida } \\
\hline Monstrilla sp. & & & $\mathrm{x}$ \\
\hline M. aff. serricornis & & $\mathrm{x}$ & \\
\hline M. helgolandica & $\mathrm{x}$ & $\mathrm{x}$ & $\mathrm{x}$ \\
\hline Amphipoda & $\mathrm{x}$ & & \\
\hline \multicolumn{4}{|l|}{ Amphipoda sp. } \\
\hline \multicolumn{4}{|l|}{ Cirripedia } \\
\hline Balanus a. amphitrite (N-C) & & & $\mathrm{x}$ \\
\hline B. glandula $(\mathrm{N}-\mathrm{C})$ & $\mathrm{x}$ & $\mathrm{x}$ & $\mathrm{x}$ \\
\hline \multicolumn{4}{|l|}{ Decapoda } \\
\hline Beteus lilianae $(\mathrm{M})$ & $\mathrm{x}$ & $\mathrm{x}$ & \\
\hline Chasmagnathus granulatus (Z) & $\mathrm{x}$ & $\mathrm{x}$ & $\mathrm{x}$ \\
\hline \multicolumn{4}{|l|}{ Mollusca } \\
\hline Gastropoda sp. (V) & $\mathrm{x}$ & & \\
\hline Bivalvia sp. (V) & $\mathrm{x}$ & & \\
\hline \multicolumn{4}{|l|}{ Cnidaria } \\
\hline Tubularia crocea (A) & & $\mathrm{x}$ & \\
\hline Olindias sambaquiensis (E) & $\mathrm{x}$ & & \\
\hline Obelia sp. & $\mathrm{x}$ & & \\
\hline \multicolumn{4}{|l|}{ Ceriantharia sp. (C) } \\
\hline \multicolumn{4}{|l|}{ Polychaeta } \\
\hline Polychaeta sp. & $\mathrm{x}$ & & $\mathrm{x}$ \\
\hline Spionidae sp.1 (N1) & $\mathrm{x}$ & $\mathrm{x}$ & $\mathrm{x}$ \\
\hline Spionidae sp. 2 (N2) & $\mathrm{x}$ & $\mathrm{x}$ & \\
\hline \multicolumn{4}{|l|}{ Bryozoa } \\
\hline Bryozoa sp. (Ci) & & $\mathrm{x}$ & \\
\hline
\end{tabular}




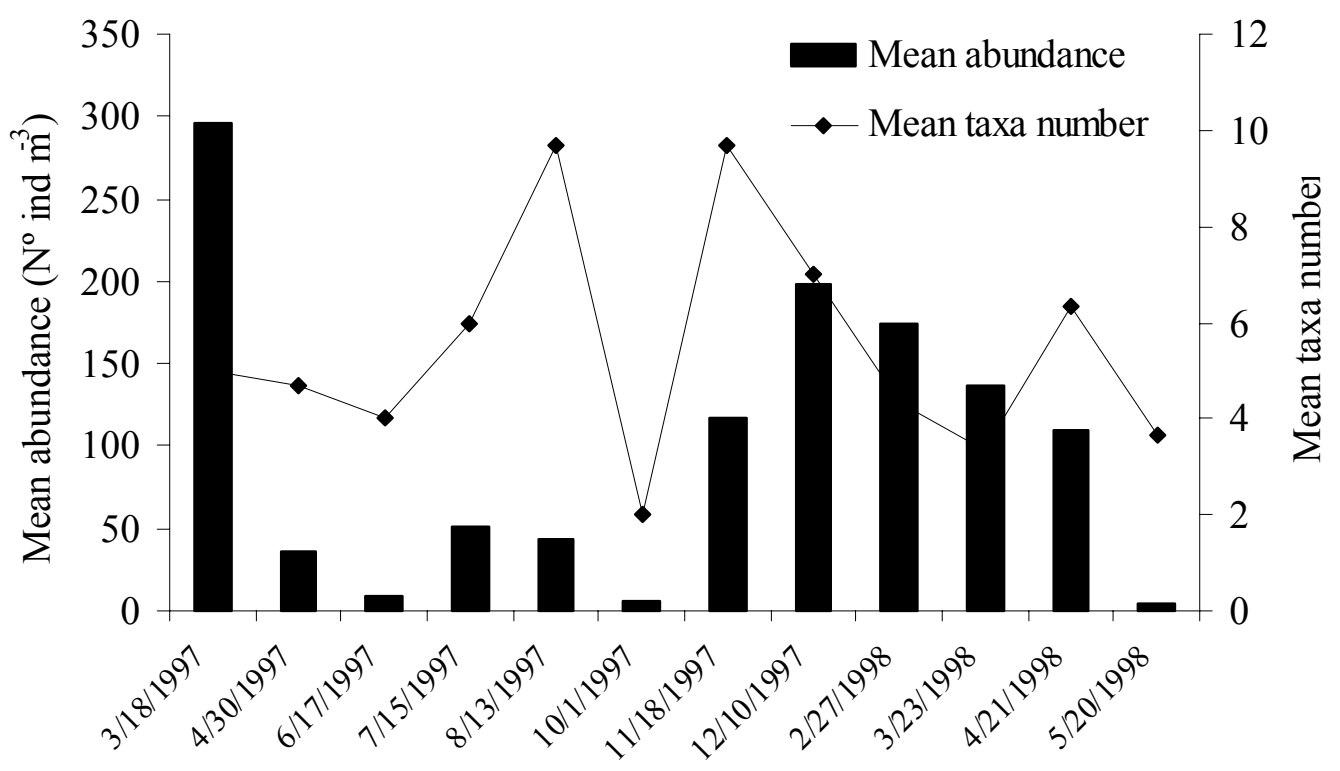

Sampling Date

Fig. 3. Seasonal variation of mean taxa number and mean abundance of mesozooplankton at Bahía del Medio channel.

estuarine areas and others linked to the flooding of the tidal flats. On the other hand, an inverse relationship between mesozooplankton richness and total abundance was observed which is similar to the inverse relationship between zooplankton abundance and diversity according to the Shannon-Wiener index, reported by Osore et al. (2004) for Mida Creek on the Kenya coast all year round.

All peaks of tintinnid abundance were observed in the autumn (Fig. 2) and were coincident with the highest temperatures, which is in agreement with the results obtained in previous works carried out in the inner part of the estuary (Barría de Cao, 1992), where peaks in abundance due to the presence of Tindinnidium balechi are common. The maximum abundance peak, however, corresponded to $M$. mereschkowskyi, a species typical of the outer part of the estuary. The peak occurred at $\mathrm{C}$, the most distant sampling point from the Main channel. This species was observed at $\mathrm{B}$ and $\mathrm{C}$ but never at $\mathrm{A}$ which is closer to the Main channel. The presence of other species typical of the outer zone at the same stations (B and C) -Favella taraikaensis and Eutintinnus lususundae- indicates the influence of a different external water mass moving across the Main channel up to the estuarine head. Similar observations were made for mesozooplanktonic species such as some first development stages of Calanoides carinatus (copepodids I and II), zoeae stages of the decapod
Beteus liliana, juvenils (ephirae) of the medusa Olindias sambaquiensis. The former is a large calanoid copepod dominant in the adjacent inner shelf, whereas the other forms are also typical of the outer estuarine waters and inner shelf.

With the exception of the above-mentioned taxa, most of the mesozooplankton groups and species found in this channel are common in the inner estuarine zone. Furthermore, the most abundant species have been frequently reported by Hoffmeyer (1983; 1994; $2004 \mathrm{a}, \mathrm{b})$ for the inner zone of the main estuary's channel. Even though the seasonal succession pattern was similar in this tidal channel, their maximal-minimal abundance peaks were lower than those previously reported for the inner zone of the estuary (Hoffmeyer, 1994). The small native calanoid copepod $A$. tonsa and the invaders E. americana and B. glandula larvae displayed a similar cycle, though the observed abundances were in general lower (Hoffmeyer, 2004 a).

The comparison between the present data for Bahía del Medio channel and those reported for Ing. White Port, at the Main channel, showed some differences (Tables $4 ; 5)$. In general, the succession of the tintinnids in the tidal channel showed a trend similar to that observed at the Main channel, the only difference being that some species such as Tintinnopsis levigata and T. baltica which showed seasonal restrictions at the Main channel were 
recorded here throughout the year (Table 4). The number of mesopanktonic taxa (32) found in this study was greater than that reported for Ing. White Port (18) during 1990-1991 (Hoffmeyer, 2004 a) (Table 5). Only 14 of them were common to both channels. The number of taxa recorded only at the Bahía del Medio channel (17, though in much lower abundance) was higher than the number reported for Ing. White Port station (3). A lower overall mesozooplankton abundance was also evident at this channel, whereas no important differences were found in the seasonality of the most abundant and common taxa.

The presence as well as the dominance of some zooplankton species in this secondary channel, different from others which are common to the inner part of the Main channel estuary, could be explained by the origin of the water mass circulating in this particular zone of the estuary. The water mass during the flow may arrive at the estuary via the southern coast of the Main channel, discharging into La Lista channel and then into this small secondary channel (Bahía del Medio) (Ginsberg, pers. comm.). It could also come from the South via Falsa Bay, a southern creek within this estuarine complex, or via the large channels (affluents to the Main channel) such as El Embudo, Tres Brazas or Cabeza de Buey at the North, before finally flowing during the ebb into the Main channel (Fig. 1; Falsa Bay, El Embudo and Tres Brazas channels are not shown in the map). The major penetration of these sporadic external water masses into the flats and tidal channels situated South of the Main channel could increase as a consequence of events such as extraordinary high tides and/or strong South-East winds. The fact that the highest salinity values were registered in this area during the autumn (a season of extraordinary tides) is probably an evidence of this phenomenon.

The occurrence of some mixohaline mesozooplankton species such as Diaptomidae sp., Halicyclops crassicornis and Cyclopina sp. in November and April-May, could be related to the connection of this tidal channel with small temporary lagoons formed during high rainfall periods.

The low density of tintinnids observed during the winter in this area is coincident with the results obtained in the inner part of the estuary (Barría de Cao, 1992). This can be explained by the dominance of thread-bearing diatoms during the phytoplankton bloom occurring annually in the estuary which in general, are not adequate food for tintinnids (Barría de Cao et al., 1997). Heterotrophic marine bacteria with peaks exceeding $100,000 \mathrm{CFU} \mathrm{ml}^{-1}$ and heterotrophic terrestrial bacteria which exceed 10,000 CFU ml ${ }^{-1}$ in winter (Baldini et al., 1999) would be the most important source of food during this season. Such bacteria are suitable food mainly for those species with small peristome, thus favoring the presence of only certain species.

Table 4. Comparison of the mean annual abundance data of tintinnids $\left(\mathrm{N}^{\circ}\right.$ ind $\left.\mathrm{x} 106 \mathrm{ind} \mathrm{m}^{-3}\right)$ registered at the tidal channel (in decreasing order) with the historic data for de Main channel, for the Ing. White Port only dominant species. * Species presentno data on abundance. Au, autumn; Wi, winter; Sp, spring; Su, summer.

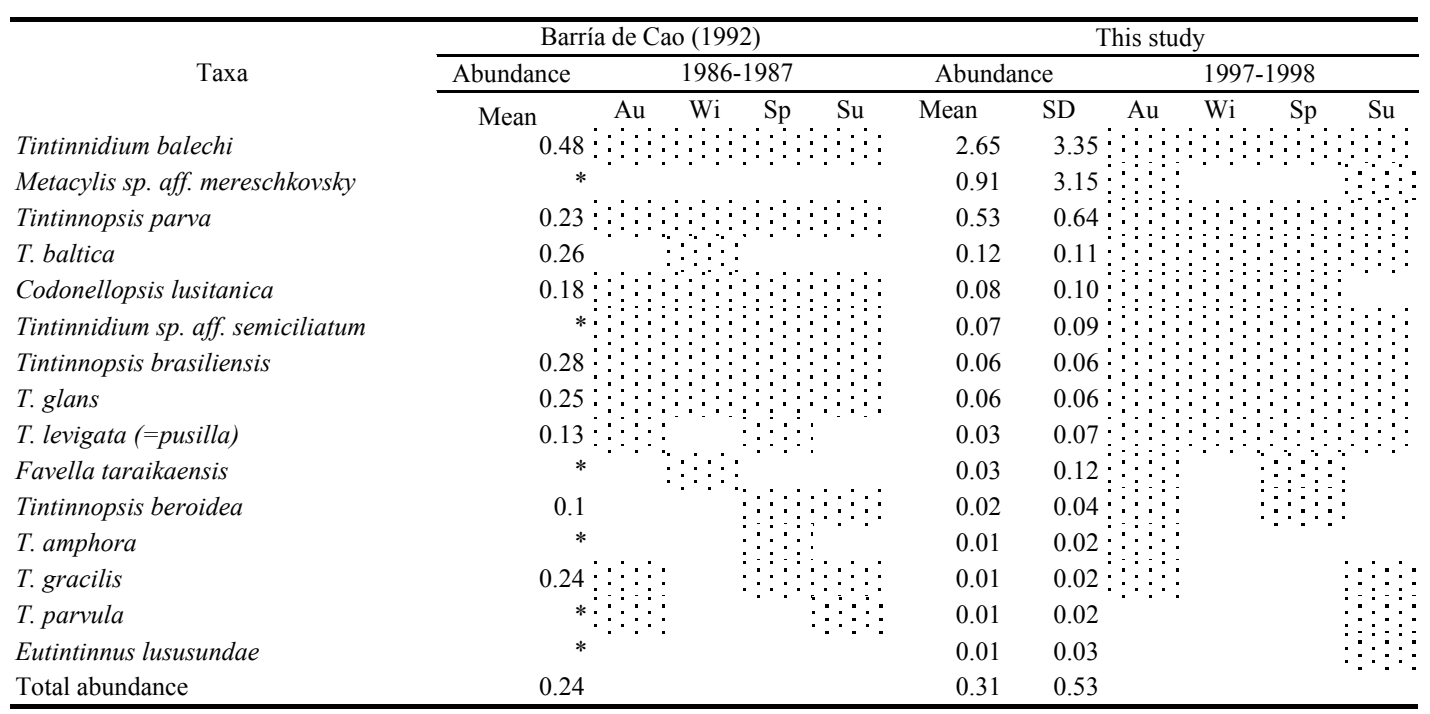


Table 5. Comparison of mean annual abundance data $\left(\mathrm{N}^{\circ}\right.$ ind. $\mathrm{m}^{-3}$ ) and SD (standard deviation) of mesozooplankton taxa, in decreasing order and seasonality data obtained in this study, with those reported for Ing White station (into the Main channel) from 1990-1991 years. ${ }^{*}$ only one value; ${ }^{* *}$ mean $=1$. Stage abbreviations as in Table 3. Ci: ciphonautes larva. Season abbreviations as in Table 4.

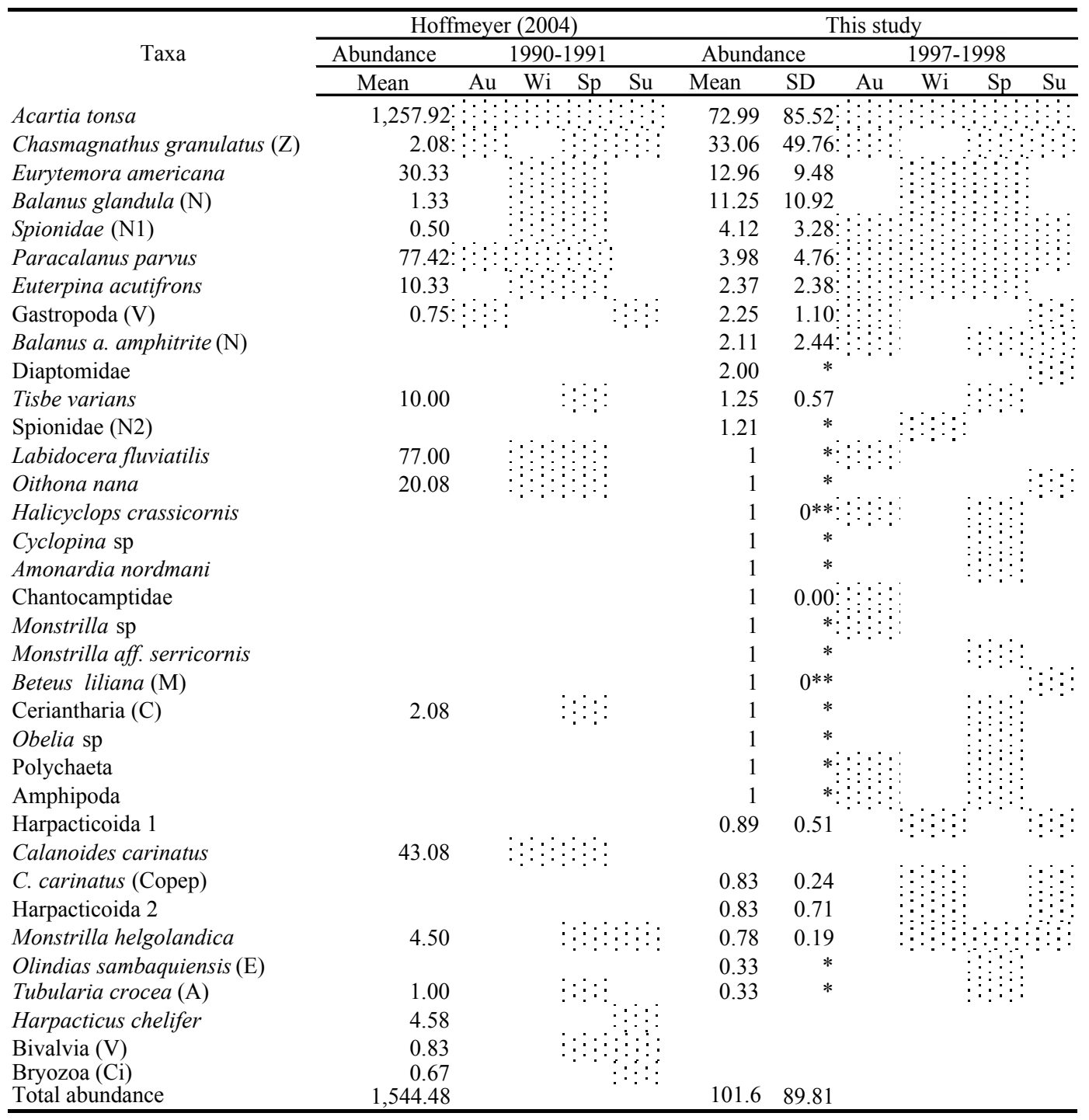

The high correlation between the abundances of tintinnids and of the omnivorous copepod Acartia tonsa found in two of the three stations analysed could be an evidence of trophic coupling. Other works (Robertson, 1983) indicate that under certain conditions, tintinnids can be an important food source for the estuarine copepod $A$. tonsa.

We have observed that hydrodynamics and tides influence the zooplankton spatial distribution; also other authors have mentioned this influence on the vertical distribution of some zooplankters inducing their migration (Kopacks, 1994).

Finally, the Bahía del Medio channel is shown to be spatially homogeneous in its physical and biochemical features. Micro and mesozooplankton abundance also displayed a high degree of spatial homogeneity, though the seasonal variation in both environment and zooplankton was significant. Comparison with the zooplankton observed at Ing. White station (in the Main channel of the estuary) showed some interesting differences in the number of 
taxa represented (increase), a generally lower abundance of micro- and mesozoopankton, and the presence of some rare species from the outer area of the estuary and others related with temporary mixohaline environments. Despite these differences, the general seasonal pattern of the two assemblages and the most abundant type of taxa were similar.

In conclusion, the differences observed in the zooplankton of the tidal channel could be the consequence of a different circulation pattern, which would also explain the physical and chemical differences between the two sites. Further coordinated studies on water mass circulation and plankton are required to corroborate this hypothesis.

\section{ACKNOWLEDGEMENTS}

We are grateful for the support provided by personnel of the oceanographic boat during the sampling surveys and staff of the Chemistry Lab of IADO. The suggestions of two anonymous reviewers on the first version of the manuscript are gratefully acknowledged. This research project was made possible by funding from UNS (Universidad Nacional del Sur), CIC (Comisión de Investigaciones Científicas, Pcia. de Buenos Aires) and (CONICET, PIP 3003/1999) grants.

\section{REFERENCES}

Aliotta, S. \& Perillo, G. M. 1987. A sand wave field in the entrance to Bahía Blanca Estuary, Argentina. Mar. Geol.., 76:1-14.

Aliotta, S.; Farinati, E.; Lizasoain, G. \& Spagnuolo, J. 1998. Sedimentos superficiales y del subsuelo marino en el Canal Cabeza de Buey-Bahía del Medio, Estuario de Bahía Blanca, Argentina. In: Jornadas Geológicas y Geofísicas Bonaerenses, V. Actas: 145-154.

Baldini, M. D.; Cubitto, M. A.; Chiarello, M. N. \& Cabezalí, C. B. 1999. Water quality for aquaculture development in Bahía Blanca estuary, Argentina. Bacteriological studies. Rev. Argentina Microbiol., 31:19-24.

Barría de Cao, M. S. 1986. Contribución al conocimiento de Tintinnina (Protozoa, Ciliophora) de la zona de Bahía Blanca, II (Argentina). Boln. Inst. esp. Oceanog., 3(1): 143-150

Barría de Cao, M. S. 1992. Abundance and species composition of Tintinnina (Ciliophora) in Bahía Blanca Estuary, Argentina. Estuar. coast Shelf Sci., 34:295303.

Barría de Cao, M. S.; Pettigrosso, R. E. \& Popovich, C. 1997. Planktonic ciliates during a diatom bloom in Bahía Blanca Estuary, Argentina. II. Tintinnids. Oebalia, 23:21-31.

Barría de Cao, M. S.; Beigt, D. \& Piccolo, C. 2006. Temporal variability of diversity and biomass of tintinnids (Ciliophora) in a southwestern Atlantic temperate estuary. J. Plankt. Res., 27 (11):1103-1111.
Cervellini, P. M. 2001. Variabilidad en la abundancia y retención de larvas de crustáceos decápodos en el estuario de Bahía Blanca, Provincia de Buenos Aires, Argentina. Invest. mar., Valparaíso, 29(2):25-33.

Cuadrado, D.; Ginsberg, S. \& Gómez, E. 2000. Características físicas de un canal de marea interior en el estuario de Bahía Blanca (Buenos Aires). III J. Nac. Geogr. Fis., Santa Fé, Argentina, 113-120.

Gayoso, A. M. 1999. Seasonal sucession patterns of phytoplankton in the Bahía Blanca Estuary (Argentina). Bot. mar., (42):367-375.

Ginsberg, S. S. \& Perillo, G. M., 2004. Characteristics of tidal channels in a mesotidal estuary of Argentina. J. coast. Res., 20(2):489-497.

Hasle, G. 1978. Concentrating phytoplankton settling. The inverted - microscope method. Phytoplankton Manual. In: Sournia, A., ed., Monographs on oceanographic methodology 6. UNESCO, p. 8-96.

Hoffmeyer, M. S. 1983. Zooplancton del área interna de la Bahía Blanca (Buenos Aires, Argentina). I- Composición faunística. Hist. Nat., 3 (8):73-94.

Hoffmeyer, M. S. 1994. Seasonal succession of Copepoda in the Bahía Blanca estuary. In: F. D. Ferrari \& B. P. Bradley, eds. Ecology and Morphology of Copepods, Developments on Hydrobiologia, 292/293: 303-308.

Hoffmeyer, M. S. 2004 a. Decadal change in zooplankton seasonal succession in the Bahía Blanca estuary, Argentina, following introduction of two zooplankton species. J. Plankt. Res., 26 (2):1-9.

Hoffmeyer, M. S. 2004 b. Mesozooplancton. In: Piccolo, M. C. \& Hoffmeyer, M S. eds., El ecosistema del estuario de Bahía Blanca, Publicación Especial Instituto Argentino de Oceanografía (CONICET-UNS), p. 133141.

Kopacs, U. 1994. Evidence for tidally-induced vertical migration of some gelatinous zooplankton in the Wadden Sea area near Sylt. Helgolander Mar. Res., 48(2/3):333342.

Lorenzen, C. L. 1967. Determinations of chlorophyll and phaeopigments. Spectrophotometric equations. Limnol. Oceanogr., 12:343-346.

Osore, M. K. W.; Mwaluma, J. M.; Fiers, F. \& Daro, M. H. 2004. Zooplankton Composition and Abundance in Mida Creek, Kenya. Zool. Stud., 43(2):415-424.

Pettigrosso, R. E.; Barría de Cao, M. S. \& Popovich, C. 1997. Planktonic ciliates during a diatom bloom in Bahía Blanca Estuary, Argentina. I. Aloricate Ciliates. Oebalia, 23:3-19.

Piccolo, M. C. \& Hoffmeyer, M. S. eds. 2004. El ecosistema del estuario de Bahía Blanca. Publicación especial del Instituto Argentino de Oceanografía (CONICET-UNS). Bahía Blanca, Argentina. 233 p.

Piccolo, M. C. \& Perillo, G. 1990. Physical characteristics of the Bahía Blanca Estuary (Argentina). Estuar. coast. Shelf Sci., 31:303-317.

Robertson, J. 1983. Predation by Estuarine Zooplankton on Tintinnids Ciliates. Estuar. coast. Shelf Sci., 16:27-36.

Seliger, H. H.; Boggs, J. A.; Rivkin, R. B.; Bigley, W. H. \& Aspden, K. R. 1982. The transport of oister larvae in estuary. Mar. Biol., 71:57-72.

Serman, D. D. 1985. Características de la marea en Bahía Blanca. Boln. Naval, 103:51-74. 
HOFFMEYER \& BARRÍA DE CAO: MICRO- AND MESOZOOPLANKTON IN AN ESTUARINE TIDAL CHANNEL 107

Sokal, R. R. \& Rohlf, F. J. 1981. Biometría. Principios y métodos estadísticos en la investigación biológica. Madrid, H. Blume eds. 832 p.

Strickland, J. D. H. \& Parsons, T. R. 1968. A practical handbook of seawater analysis. Fish. Res. Bd. Can. 311 p.

Valiela, I. 1995. Marine Ecological Processes. $2^{\text {nd }}$ ed. Berlin: Springer Verlag. $686 \mathrm{p}$.
Sources of Unpublhished Material

Angeles, G. R. 2002. Estudio integrado del estuario de Bahía Blanca, Argentina. Doctoral Thesis. Universidad Nacional del Sur. 187 pp.

(Manuscript received 16 February 2006; revised 07 August 2006; accepted 23 February 2007) 